\title{
對스리랑카 원조동향
}

스리랑카 언론 및 각 원조기관 주재 사무소와 접 촉, 확인한 지난 7월의 붕스리랑카 주요 원조동향은 아래와 같음.

\section{1. 세계은행(World Bank)}

ㅁ세계은행은 스리랑카 교육발전 프로그램을 지원 하기 위해 2006년부터 2010년까지 스리랑카 교육 부에 최대 6천만불을 지원할 계획임을 발표함.

ㅁ 세계은행 관계자는 스리랑카 내 각급 학교와 지역 교육의 질, 접근의 용이성, 표준향상을 위한 정부 의 노력들을 치하하는 한편, 향후 지역간 교육수준 의 평준화에 더욱 노력해야 함을 강조함.

ㅁ스리랑카 정부는 경제성장과 빈곤퇴치 전략에서 교육이 차지하는 중요성을 인식하고, 동 지원금을 통해 고등학교를 졸업한 10 만 명의 모든 학생들에 게 대학 진학이 가능하도록 활용하는 한편, 2006 년부터 학교중심 경영을 도입하여 IT, 과학 및 수 학분야 등에 중점 투자하여 세계수준에 걸맞는 현
대화를 도모할 예정임을 밝힘.

\section{2. 세계식량기구(World Food Programme)}

ㅁ세계식량기구는 쓰나미 피해 주민의 식량 및 스리 랑카 식량안전대책의 일환으로 스리랑카 농민으로 부터 쌀 1만 8천여metric톤을 매입하기로 결정하 였으며, 이는 그동안 국제기구가 스리랑카 현지농 민들로부터 매입한 쌀 분량 중에서 제일 큰 규모임. ㅁ 세계식량기구는 이를 위해 519만불을 투자키로 스 리랑카 농업, 축산 및 토지부와 서약하였으며, 일 본 및 호주 정부는 쌀 매입을 위해 세계식량기구에 재정적 지원을 하기로 약속함.

- 일본을 통해 13,000 metric톤, 호주 정부를 통해

5,130metric톤 구입 예정

ㅁ 전체 쌀 매입은 스리랑카 식량안전대책을 위해 활 용되어질 계획이며, 특히 쓰나미 피해 주민들에게 무상으로 배부될 예정임. 따라서 동 쌀 매입 프로 젝트는 운송과 배부에 필요한 구직기회를 제공하 
는 한편 스리랑카 시장경제의 쌀값 안정에 기여할 것으로 예상됨.

ㅁ 세계식량기구는 동 프로젝트를 위해 이미 농민들 로부터 8,080metric톤을 매입하였으며 그동안 55,000 metric톤의 식량 저장품을 쓰나미 피해지 역 주민들에게 분배함.

\section{3. 호주}

ㅁㅎㅈㅜ 정부는 쓰나미 피해를 입은 Mannar 및 Vavunia지역 내에 생활수단을 잃은 주민들의 재 배치 및 재정착을 위해 UNDP에 320만불을 지원 키로 함.

UNDP에 의해 추진될 동 프로젝트는 영구주택 설 계, 어업 및 농업 기자재 분야에 지원될 예정이며 인도에서 귀국하는 스리랑카 피난민들도 포함됨.

\section{4. 중국}

므스리랑카와 중국 정부간 이중과세 및 탈세방지를 위한 협정이 2005년 5월 23일부터 효력이 발효됨. - 스리랑카에 기술전수와 투자촉진을 유도하는 많은 타국 합의서들과 비슷한 형태를 띤 동 합의 서는 제 28 조 규정에 따라 평가기간을 고려해 스 리랑카에서 2006년 4월 1일부터 적용될 예정임.

- 동 합의서는 규정 강화를 촉진시키기 위한 스리 랑카와 중국간의 정보공유를 제공하고 수입관 세에 대한 탈세방지를 지원하며 배당금, 이자 및 사용료에 대한 세금비율은 다음과 같이 동의함

* 배당금 : $10 \%$, 이자 : $10 \%$, 사용료 : $10 \%$

ㅁㅏㅏㄴ편 스리랑카 정부와 중국 정부는 관광분야 협력
을 위해 아래 사항들을 내용으로 하는 MOU를 체 결하였으며, 스리랑카는 2006년도에 $\mathrm{BOI}$ 및 관광 청 사무실을 상하이와 북경에 설치할 예정임.

- 관광부문의 긴밀체계 논의를 위한 정기적 모임

- 관광산업, 특히 호텔산업의 합동투자 촉진

- 관광산업 관련 스리랑카의 중국호텔학교에 훈 련프로그램 전수

- 관광산업 관련 스리랑카의 중국국가에 일반 관 광 전수

- 중국시장에서의 스리랑카 관광 촉진 조장

- 중국 웹사이트 설치 지원

\section{5. 파키스탄}

므르리랑카와 파키스탄과의 자유무역협정이 발효될 경우 금년도 양국간 교역규모는 3억불 수준에 이 를 것으로 '파키스탄 타임지' 는 예상함.

- 차, 구장잎, 면 등과 같은 상품 교역은 2 배 이상 증대

2004년도 파키스탄의 스리랑카 수출은 970만불, 2003년도 스리랑카의 파키스탄 수출은 480만불 이었으며, 파키스탄 내각에서 지난 4월 12 일 자유 무역협정에 동의함에 따라 양국간 조약체결이 조 만간 이루어질 것으로 예견함.

\section{6. 세계은행 및 아시아개발은행}

미속되는 정치적 불안으로 스리랑카의 투자전망 이 불투명해짐에 따라 스리랑카 정부는 파트너십 을 유지하는데 많은 노력을 기울이고 있다고 아시 아개발은행 및 세계은행은 지적함. 
ㅁ 상기 2 개 은행의 합동조사서는 스리랑카의 정치적 부패감소에도 불구하고 빈약한 재정접근, 빈약한 하부구조체계, 지속적인 불안정 등은 스리랑카에 대한 투자욕구에 부정적인 영향을 미치고 있다고 지적하면서 평화적 협상 및 정치적 안정성 확보가 스리랑카에 대한 투자를 촉진시키기 위한 선결 과 제라고 설명함.

ㅁ동 조사서는 또한, 열악한 교통편, 공공재정부문 의 제한적 접근 및 빈번한 정전은 지방의 소규모사 업에 지장을 초래하며 비록 $90 \%$ 가까운 도로망 설 치에도 불구하고 열악한 도로 유지보수로 어려움 을 겪고 있으나 스리랑카 통신부문은 성공적으로 사업을 이끌고 있고 의류, 농장 및 항공부문도 비 슷한 경우라고 언급함.

[자료:주스리랑카 대사관] 